\title{
ELECTRICAL CONDUCTIVITY AS AN INDICATOR OF PEA SEED AGING OF STORED AT DIFFERENT TEMPERATURES
}

\author{
Maristela Panobiancoํㅜ Roberval Daiton Vieira ${ }^{2 *}$; Dilermando Perecin ${ }^{3}$ \\ ${ }^{1}$ UFPR/SCA - Depto. de Fitotecnia e Fitossanitarismo, R. dos Funcionários, 1540 - 80035-050 - Curitiba, PR - \\ Brasil. \\ ${ }^{2}$ UNESP/FCAV - Depto. de Produção Vegetal, Via de Acesso Prof. Paulo Donato Castellane, s/n - 14884-900 - \\ Jaboticabal, SP - Brasil. \\ UNESP/FCAV - Depto. de Ciências Exatas, Via de Acesso Prof. Paulo Donato Castellane, s/n - 14884-900 - \\ Jaboticabal, SP - Brasil. \\ *Corresponding author 〈rdvieira@fcav.unesp.br>
}

\begin{abstract}
Research on soybean seed has revealed that conductivity test results may be influenced by storage temperature and that an apparent direct relationship between deterioration at low temperatures and loss of cellular membrane integrity is not evident. The objective of this study was to verify the influence of low storage temperatures on electrical conductivity results in other species, such as seeds of two pea cultivars studied temperatures were: $10,20,25,20 / 10$ and $25 / 10^{\circ} \mathrm{C}$. The physiological potential of the seeds was evaluated every three months during an 18 month storage period using germination, accelerated aging and electrical conductivity tests. The electrical conductivity test was not a good indicator for the degree of seed deterioration stored at low temperatures. Seed deterioration at $10^{\circ} \mathrm{C}$ did not seem to be directly related to the loss of membrane integrity, possibly due to membrane repair or reorganization during storage at this temperature.
\end{abstract}

Key words: Pisum sativum L., vigor, physiological quality

\section{CONDUTIVIDADE ELÉTRICA DE SEMENTES DE ERVILHA APÓS ARMAZENAMENTO SOB DIFERENTES TEMPERATURAS}

\begin{abstract}
RESUMO: Pesquisas com sementes de soja têm revelado que os resultados do teste de condutividade elétrica podem ser influenciados pela temperatura de armazenamento, sugerindo que a deterioração das sementes em temperaturas baixas parece não estar relacionada diretamente com a perda da integridade das membranas celulares. O presente estudo foi conduzido com o objetivo de verificar se a influência de baixas temperaturas de armazenamento nos resultados da condutividade elétrica ocorre também para outra espécie, sendo utilizadas para tanto, sementes de dois cultivares de ervilha. O efeito das seguintes temperaturas foi estudado: $10,20,25,20 / 10$ e $25 / 10^{\circ} \mathrm{C}$. A cada três meses, num total de 18 meses de armazenamento, foi avaliado o potencial fisiológico das sementes usando-se os testes de germinação, envelhecimento acelerado e condutividade elétrica. O teste de condutividade elétrica não se mostrou um bom indicador da intensidade do processo de deterioração de sementes armazenadas a baixas temperaturas. A deterioração das sementes a $10^{\circ} \mathrm{C}$ parece não estar relacionada diretamente com a perda da integridade das membranas, possivelmente devido ao reparo ou à reorganização das mesmas durante o período de armazenamento nesta temperatura.
\end{abstract}

Palavras-chave: Pisum sativum L., vigor, qualidade fisiológica

\section{INTRODUCTION}

Organization of cellular membranes is at its peak by the time a seed reaches physiological maturity (Abdul-Baki, 1980). Seeds undergo a structural disorganization process during the drying period before harvest; the lower the water content, the greater the disorganization. As a result seeds temporarily lose their integrity (Bewley \& Black, 1994). During the initial phase of the soaking process, the capacity of a seed to reorga- nize the cellular membrane system and repair physical and/or biological damage that may have occurred, will influence the quantity and nature of the lixiviates released into the environment (Simon \& Raja Harun, 1972; Bewley \& Black, 1994; Vieira \& Krzyzanowski, 1999). Thus, seeds with less physiological potential as a result of the deteriorative process have a reduced capacity for membrane reorganization and a greater loss of solutes to the environment, resulting in decreased seed reserves and reduced germination uniformity and speed. 
Soaking liberates sugars, amino acids, fatty acids, enzymes and ions in quantities varying according to the organizational state of the cellular membrane systems (Simon \& Raja Harun, 1972; Short \& Lacy, 1976; Givelberg et al., 1984; Woodstock, 1988; Bewley \& Black, 1994; Taylor et al., 1995). Release of solutes and water absorption are very high at the beginning of the soaking process; however, the rate at which the membranes reorganize decreases with seed age (Abdel Samad \& Pearce, 1978; Simon \& Mathavan, 1986).

Electrical conductivity was proposed as a test to determine the physiological potential of seeds. Its objective was to indirectly evaluate the degree of cellular membrane damage resulting from seed deterioration, by means of determining the quantity of lixiviated ions in a solution with a fixed volume of deionized water, in which a known number of seeds are soaked at a controlled temperature for a pre-established period of time. Seeds with lower physiological potential liberate a greater amount of electrolytes as a consequence of lower cellular membrane selectivity. Decreased physiological potential and seed germination are directly related to increased quantities of lixiviated solutes resulting from a loss of membrane integrity (Loeffler et al., 1988; Marcos-Filho et al., 1990 and Vieira et al., 1999).

The electrical conductivity test has been recommended to evaluate seed vigor for peas. It has also been suggested for soybean seeds (Hampton \& TeKrony, 1995). Despite specific recommendations for these two species, the test has been studied for use with other crops due to its simplicity in execution and rapid response (Vieira \& Krzyzanowski, 1999). Although the electrical conductivity test is often done on a routine basis in seed laboratories, the technique has been applied in only a few studies to estimate the effect of storage on seed vigor. Some studies have indicated that electrical conductivity results may be influenced by storage temperature especially the lower ones. Ferguson (1988) observed that soybean seeds stored at $10^{\circ} \mathrm{C}$ (temperature normally utilized in a cold chamber) had a reduced physiological potential when evaluated by germination and accelerated aging tests; however, this reduction was not detected by the electrical conductivity test.

With the objective of investigating the effect of storage temperature on seed deterioration in soybean, Vieira et al. (2001) evaluated six seed lots with distinct physiological potentials. They observed that at $10^{\circ} \mathrm{C}$, germination obtained after accelerated aging was reduced for all stored lots, while electrical conductivity data did not vary during the same period.
Seed samples stored at $20^{\circ} \mathrm{C}$ presented rapidly decreasing values for standard germination and accelerated aging tests, accompanied by increased electrical conductivity values.

When seed samples were transferred from $20^{\circ} \mathrm{C}$ to $10^{\circ} \mathrm{C}$ after six months storage, accelerated aging test results showed that there was a continuing decline in vigor but that the electrical conductivity values remained stable. This fact led the authors to question the use of electrical conductivity as an indicator of deterioration and seed vigor in soybean after storage at low temperatures. In a more recent study, Fessel (2001) sought to confirm the influence of storage at $10^{\circ} \mathrm{C}$ on electrical conductivity results and verified that this test was also not indicated for evaluating seed vigor in soybean under cold storage. On the other hand, seed deterioration at $10^{\circ} \mathrm{C}$ does not seem to be directly related to loss of membrane integrity, which may be due to its repair or reorganization during storage at lower temperatures.

Although there are several studies on the effect of storage temperature $\left(10^{\circ} \mathrm{C}\right.$ in particular) on electrical conductivity test results in soybean, more detailed studies are needed for other species, especially to verify the influence of low storage temperatures. Consequently, the present research study was carried out on pea seeds with the objective of studying the effect of different storage temperatures on electrical conductivity results. The choice of this species is justified by the fact that this test is already considered to be sufficiently standardized for pea (Hampton \& TeKrony, 1995).

\section{MATERIAL AND METHODS}

The study was made between November 2003 and July 2005 in Jaboticabal, SP, Brazil. Lots with distinct physiological potentials (one superior and one inferior) were selected from the pea cultivars DILETA and MARINA (Table 1).

Seed water content was initially adjusted around $12 \%$ using the following procedures: a) Drying (when initial water content was greater than $12 \%$ ): each sample was spread on a polystyrene tray and placed in a dryer with forced air circulation at a temperature varying between 30 and $33^{\circ} \mathrm{C}$; b) Moistening (when initial water content was less than $12 \%$ ): a single layer of seeds was laid on an internal screen inside adapted plastic boxes $(26.0 \times 16.0 \times 8.5 \mathrm{~cm})$, filled with $500 \mathrm{~mL}$ water, covered and maintained in an incubator at $20^{\circ} \mathrm{C}$. Seed water content was monitored during artificial drying and moistening by successive weighing until the desired level was obtained. As soon as the desired water content was reached, 
Table 1 - Initial water content (WC) of the seeds, standard germination (SG), accelerated aging (AA) and electrical conductivity (EC) of pea seeds of the cultivars DILETA and MARINA.

\begin{tabular}{lcccc}
\hline Pea seed lot & \multicolumn{4}{c}{ Parameters } \\
\hline & WC & SG & AA & EC \\
\hline cv. DILETA & & & & \\
Lot 1 & 11.2 & $91 \mathrm{a}$ & $83 \mathrm{a}$ & $16 \mathrm{a}$ \\
Lot 2 & 11.5 & $86 \mathrm{~b}$ & $71 \mathrm{~b}$ & $20 \mathrm{~b}$ \\
\hline Coef. of Variation $(\%)$ & - & 1.87 & 2.47 & 5.34 \\
\hline cv. MARINA & & & & \\
Lot 1 & 11.3 & $82 \mathrm{~b}$ & $68 \mathrm{~b}$ & $27 \mathrm{~b}$ \\
Lot 2 & 11.3 & $91 \mathrm{a}$ & $80 \mathrm{a}$ & $18 \mathrm{a}$ \\
\hline Coef. of Variation $(\%)$ & - & 2.20 & 2.30 & 4.30 \\
\hline
\end{tabular}

Means compared within a column by a Tukey test at a $5 \%$ probability level.

each sample was transferred to an aluminum container, hermetically closed and duly identified.

Samples were stored at the following temperatures: a) $10^{\circ} \mathrm{C}$ (constant); b) $20^{\circ} \mathrm{C}$ (constant); c) $25^{\circ} \mathrm{C}$ (constant); d) $20^{\circ} \mathrm{C}$ for six months then $10^{\circ} \mathrm{C}$ until the end of storage; e) $25^{\circ} \mathrm{C}$ for six months then $10^{\circ} \mathrm{C}$ until the end of storage. The use of the latter seeks to verify if seeds stored at a higher temperature maintain their physiological quality or delay their deterioration process when transferred to an environment at lower temperatures.

The following tests were used to evaluate the pea seeds every three months during the 18 month storage period: Germination -four replications of 50 seeds of each lot were sown in rolled paper towels (Germitest, specifically made for germination) moistened with a quantity of water equal to 2.5 times the weight of the substrate, and incubated at $20^{\circ} \mathrm{C}$. Evaluations took place five and eight days after sowing, following the criteria established by the Rules for Seed Analysis (Brasil, 1992); Accelerated Aging conducted inside plastic boxes $(11.0 \times 11.0 \times 3.5 \mathrm{~cm})$ as individual compartments (mini-chambers) with an aluminum mesh screen on which seeds were distributed in a single layer, and $40 \mathrm{~mL}$ deionized water was added to each individual compartment. The boxes were then covered and maintained in an aging chamber ("water jacketed" model) at $42^{\circ} \mathrm{C}$ for $48 \mathrm{~h}$ (Caliari \& Marcos-Filho, 1990). After aging, the seeds were submitted to a germination test. Evaluation took place five days after sowing by calculating the percentage of normal seedlings; Bulk electrical conductivity fifty seeds of each replication were weighed $(0.01 \mathrm{~g}$ precision) and soaked in $500 \mathrm{~mL}$ plastic cups contain- ing $250 \mathrm{~mL}$ deionized water, for $24 \mathrm{~h}$ at $20^{\circ} \mathrm{C}$ (Hampton \& TeKrony, 1995). Afterwards, the electrical conductivity of the solution was determined through reading in a conductivimeter (DIGIMED DM-31) and the average values obtained for each lot were expressed as $\mu \mathrm{S} \mathrm{cm}^{-1} \mathrm{~g}^{-1}$.

Trials were set up in a randomized complete design with four replications per treatment. Results were submitted to an analysis of variance and means were compared by a Tukey test at a $5 \%$. Correlation analyses were established between storage periods (months) and the results of each test.

\section{RESULTS AND DISCUSSION}

Germination of DILETA (Figure 1) and MARINA (Figure 2) pea cultivars decreased over the storage periods $(3,6,9,12,15$ and 18 months) and storage temperatures $\left(10,20,25,20 / 10\right.$ and $\left.25 / 10^{\circ} \mathrm{C}\right)$. The higher the storage temperature, the lower was the physiological quality of the seeds. Transfer to a lower temperature after six months storage at $20 / 10^{\circ} \mathrm{C}$ and $25 / 10^{\circ} \mathrm{C}$ decreased germination further. This behavior was observed in seeds with superior or inferior physiological potential of both cultivars.

Accelerated aging reduced seed germination in all treatments (Figures 1 and 2). Decrease in germination was accentuated by the higher temperature treatments. In the case of storage at $20 / 10^{\circ} \mathrm{C}$ and $25 /$ $10^{\circ} \mathrm{C}$, transference to the lower temperature $\left(10^{\circ} \mathrm{C}\right)$ after six months did not delay the seed deterioration process.

Storage at $10^{\circ} \mathrm{C}$ did not have any effect on electrical conductivity test results through the storage periods $(3,6,9,12,15$ and 18 months). Contrary to results of the germination and accelerated aging tests, electrical conductivity apparently indicated that seeds maintained their physiological quality when stored at the lowers temperature $\left(10^{\circ} \mathrm{C}\right)$. The higher temperature treatments $\left(20\right.$ and $\left.25^{\circ} \mathrm{C}\right)$ resulted in changes in electrical conductivity for all storage periods, revealing increased loss of lixiviates over time. In the above test, liberation of a greater quantity of exudates to the soaking solution was related to seeds with lower physiological potential, revealing greater intensity of disorganization of the cellular membrane systems.

Treatments in which seeds were transferred to $10^{\circ} \mathrm{C}$ after six months at either $20^{\circ} \mathrm{C}$ or 25 resulted in lower electrical conductivity readings after nine or more months storage as compared to treatments in which seeds were stored at a constant temperature, i.e., $20^{\circ} \mathrm{C}$ and $25^{\circ} \mathrm{C}$. However, this transference not result in delayed seed deterioration; electrical conductivity values increased through the evaluated periods. 

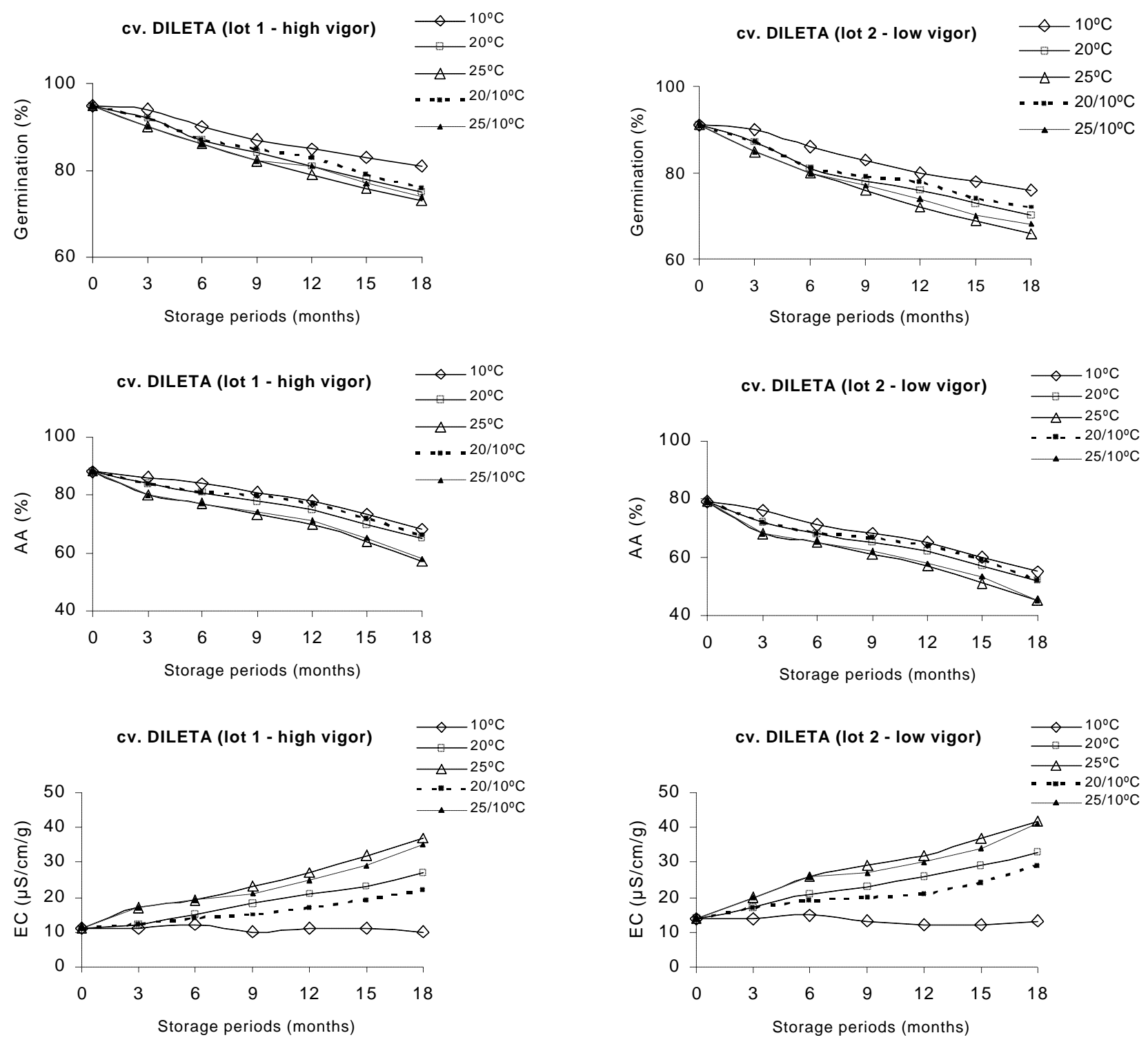

Figure 1 - Data of standard germination, accelerated ageing (AA) and electrical conductivity (EC) tests of pea seeds, cultivar DILETA, lots 1 (high vigor) and 2 (low vigor).

The data obtained with pea seeds stored at $10^{\circ} \mathrm{C}$ agree with those found in the literature for soybean (Ferguson, 1988; Vieira et al., 2001). This indicates that the release of ions by seeds may be influenced by the storage temperature; consequently, this test may not be the best indicator for the degree of deterioration for seeds stored at low temperatures.

Seed hydration allows the cellular membrane structure to be reorganized, thereby reducing permeability and consequently the liberation of lixiviates (Bewley \& Black, 1994). On the other hand, results of the present study suggest that, during imbibition, membranes are also reestablished in pea seeds when stored at low temperatures, since no increase was observed in electrical conductivity values over time.

\section{CONCLUSIONS}

The electrical conductivity test was not a good indicator for the intensity of deterioration of pea seeds stored at low temperatures. The accelerated aging test was more sensitive in detecting seed deterioration at lower storage temperatures than electrical conductivity. Seed deterioration at $10^{\circ} \mathrm{C}$ appeared not to be directly related to loss of membrane integrity.

\section{ACKNOWLEDGEMENTS}

To the FAPESP for scholarship and financial support, and to $\mathrm{CNPq}$ for a research scholarship. 

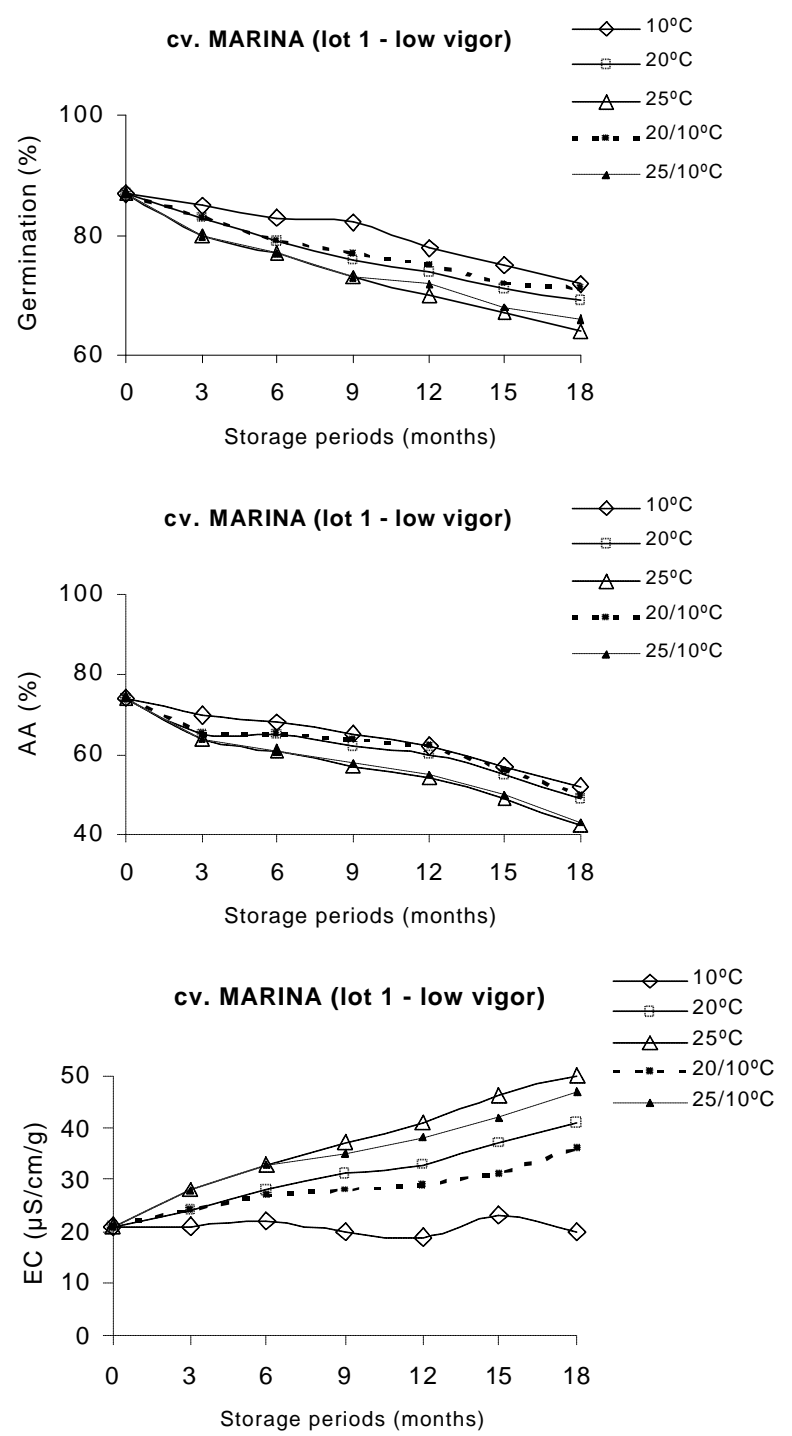
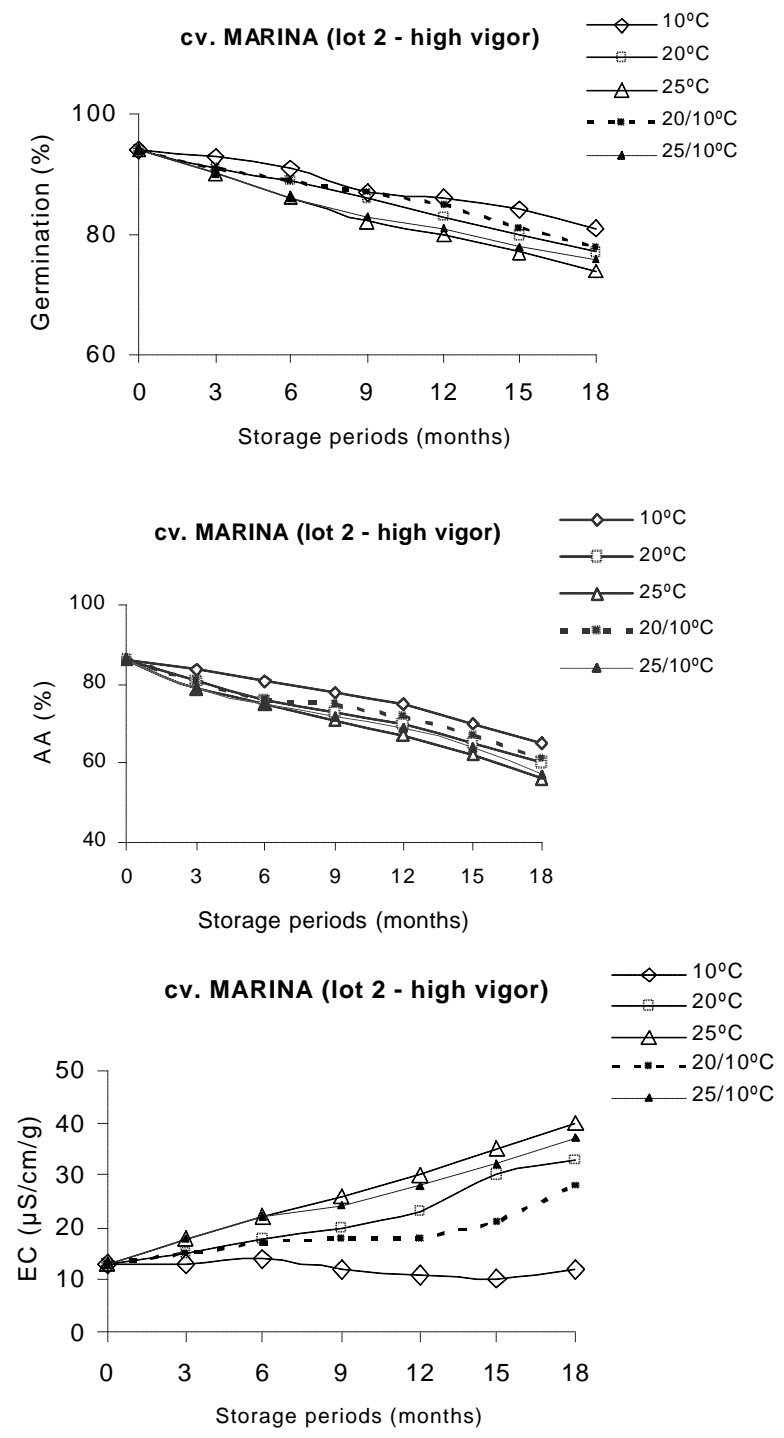

Figure 2 - Data of standard germination, accelerated ageing (AA) and electrical conductivity (EC) tests of pea seeds, cultivar MARINA, lots 1 (low vigor) and 2 (high vigor).

\section{REFERENCES}

ABDEL SAMAD, I.M.; PEARCE, R.S. Leaching of ions, organic molecules, and enzymes from seeds of peanut (Arachis hypogea $\mathrm{L}$.) imbibing without testas or with intact testas. Journal of Experimental Botany, v.29, p.1471-1478, 1978.

ABDUL-BAKI, A.A. Biochemical aspects of seed vigour. HortScience, v.15, p.765-771, 1980.

BEWLEY, J.D.; BLACK, M. Seeds: Physiology of development and germination. New York: Plenum Press, 1994. 444p.

BRASIL. Ministério da Agricultura. Regras para análise de sementes. Brasília: SNDA/DNDV/CLAV, 1992. 365p.

CALIARI, M.F.; MARCOS-FILHO, J. Comparação entre métodos para avaliação da qualidade fisiológico de sementes de ervilha (Pisum sativum L.). Revista Brasileira de Sementes, v.12, p.52-73, 1990.

FERGUSON, J.M. Metabolic and biochemical changes during the early stages of soybean seed deterioration. Lexington: University of Kentucky, 1988. 138p. (Ph.D. - Thesis).

FESSEL, S.A. Condutividade elétrica em sementes de soja em função da temperatura e do período de armazenamento. Jaboticabal: UNESP/FCAV, 2001. 100p. (Dissertação - Mestrado).
GIVELBERG, A.; HOROWITZ, M.; POLJAKOFF-MAYBER, A. Solute leakage from Solanum nigrum L. seeds exposed to high temperatures during imbibition. Journal of Experimental Botany, v.35, p.1754-1763, 1984.

HAMPTON, J.G.; TeKRONY, D.M. Handbook of vigor test methods 3.ed. Zurich: ISTA, 1995. 117p.

LOEFFLER, T.M.; TEKRONY, D.M.; EGLI, D.B. The bulk conductivity test as an indicator of soybean seed quality. Journal of Seed Technology, v.12, p.37-53, 1988.

MARCOS-FILHO, J.; SILVA, W.R.; NOVEMBRE, A.D.C.; CHAMMA, H.M.C.P. Estudo comparativo de métodos para a avaliação da qualidade fisiológica de sementes de soja, com ênfase ao teste de condutividade elétrica. Pesquisa Agropecuária Brasileira, v.25, p.1805-1815, 1990.

SHORT, G.E.; LACY, M.L. Carbohydrate exudation from pea seeds: effect of cultivar, seed age, seed color, and temperature. Phytopathology, v.66, p.182-187, 1976.

SIMON, E.W.; MATHAVAN, S. The time-course of leakage from imbibing seeds of different species. Seed Science and Technology, v.14, p.9-13, 1986.

SIMON, E.W.; RAJA HARUN, R.M. Leakage during seed imbibition. Journal of Experimental Botany, v.23, p.1076-1085, 1972. 
TAYLOR, A.G.; LEE, S.S.; BERESNIEWICZ, M.M.; PAINE, D.H. Amino acid leakage from aged vegetable seeds. Seed Science and Technology, v.23, p.113-122, 1995.

VIEIRA, R.D.; KRZYZANOWSKI, F.C. Teste de condutividade elétrica. In: KRZYZANOWSKI, F.C.; VIEIRA, R.D.; FRANÇA-NETO, J.B. (Ed.). Vigor de sementes: conceitos e testes. Londrina: Abrates, 1999. cap.4, p.1-26.

VIEIRA, R.D.; PAIVA A., J.A.; PERECIN, D. Electrical conductivity and field performance of soybean seeds. Seed Technology, v.21, p.1524, 1999.
VIEIRA, R.D.; TEKRONY, D.M.; EGLI, D.B.; RUCKER, M. Electrical conductivity of soybean seeds after storage in several environments. Seed Science and Technology, v.29, p.599-608, 2001.

WOODSTOCK, L.W. Seed imbibition: a critical period for successful germination. Journal of Seed Technology, v.12, p.1-15, 1988.

Received January 19, 2006

Accepted January 30, 2007 